\title{
Gut
}

Leading article

\section{Helicobacter pylori in gastro-oesophageal reflux disease: causal agent, independent or protective factor?}

\section{Introduction}

Helicobacter pylori causes chronic gastritis with variable activity and topographic distribution. Patient age at acquisition, expression of gastritis, strain virulence, host factors, and environmental factors determine the outcome of the infection. Well established consequences are peptic ulcer disease (PUD) and gastric neoplasia. ${ }^{1-4}$

As duodenal ulcer is often associated with gastrooesophageal reflux disease (GORD), ${ }^{5}$ and antral gastritis is a frequent finding in patients with reflux disease, ${ }^{6} \mathrm{H}$ pylori infection may be a common cause of both conditions. Our aim was to explore the strength of the postulate that $H$ pylori is a causal factor in GORD by reviewing publications on epidemiological studies, clinical observations or treatment trials, and identifying possible pathogenic mechanisms.

\section{Association of $H$ pylori and GORD}

Currently, we have no clear data to show that patients with GORD are more frequently infected by $H$ pylori than controls, neither in adults nor in children. ${ }^{7}$ Indeed, a recent well designed case control study from Japan showed a significantly lower incidence of $H$ pylori infection in patients with reflux oesophagitis than in age and sex matched controls. ${ }^{8}$ This finding is supported by one of our own studies. $^{9}$ The prevalence of both $H$ pylori infection and GORD increases with age. ${ }^{10}{ }^{11}$ Male sex is a risk factor for GORD, ${ }^{12}$ but the prevalence of $H$ pylori is equally distributed between men and women..$^{12}$

$H$ pylori is able to colonise Barrett's epithelium. Many uncontrolled studies showed $H$ pylori prevalence rates similar to those in the background population. ${ }^{7}$ Also, in a controlled study the prevalence of $H$ pylori infection was similar in patients with Barrett's oesophagus and controls. ${ }^{13}$ However, patients with Barrett's oesophagus and an ulcer within the columnar metaplasia were more frequently infected by $H$ pylori than those without ulcers. ${ }^{14}$

The prevalence of $H$ pylori infection is decreasing steadily in white adults in developed countries. ${ }^{15}$ This is paralleled by an increasing incidence of primary adenocarcinoma of the oesophagus as a consequence of reflux disease. ${ }^{16}$ Moreover, adenocarcinomas in the oesophagus are uncommon among black patients ${ }^{16}$ who have a high prevalence of $H$ pylori infection, ${ }^{17}$ and a recent study suggests that $H$ pylori induced gastritis may protect against cancer of the cardia. ${ }^{18}$ These epidemiological data do not primarily support a role for $H$ pylori in GORD, but this finding does not rule out the pathogenic importance of the infection in $H$ pylori positive reflux disease. Moreover, the infection might be involved in the pathogenesis of Barrett's ulcer. In contrast, the epidemiological data tend to support the hypothesis that $H$ pylori infection may protect to some extent against reflux disease and, most importantly, against adenocarcinoma of the gastro-oesophageal junction. Cancers at this site are now recognised as a possible complication of GORD.

\section{Current concepts of the pathogenesis of GORD}

Gastro-oesophageal reflux disease is a common disorder characterised by abnormal exposure of the oesophageal mucosa to acidic gastric contents. This may cause symptoms or mucosal damage, or both, of variable severity. Primarily, GORD is a motility disorder associated with incompetence of the lower oesophageal sphincter (LOS) and crural diaphragm. The spectrum of disturbances of the LOS extends from inappropriate transient relaxations to a persistently low basal pressure. ${ }^{19}{ }^{20}$ Although acidity in the oesophagus is a key factor in the pathogenesis, gastric acid secretion is similar in patients with reflux oesophagitis and appropriate controls. ${ }^{21}$ However, patients with very high acid secretion are at risk of developing reflux oesophagitis, ${ }^{22}$ and gastric acid hypersecretion has been found in refractory GORD. ${ }^{23}$ A substantial proportion of patients with GORD have delayed gastric emptying ${ }^{24}$ which might adversely affect the response to medical treatment. ${ }^{25}$ Furthermore, a high gastro-oesophageal pressure gradient - for example, as a result of disturbed gastric accommodation to a meal, ${ }^{26}$ motility disorders of the oesophagus with delayed clearance of refluxed gastric contents, ${ }^{27}$ impaired mucosal defence mechanisms, ${ }^{28}{ }^{29}$ diminished production of saliva, ${ }^{30}$ and environmental factors such as a high fat diet, smoking and alcohol consumption, may contribute to this multifactorial disease. ${ }^{31-33}$

\section{Mechanisms by which $H$ pylori might contribute to the pathogenesis of GORD \\ $H$ pylori frequently colonises the gastric cardia and may, in turn, exert direct and indirect effects on the LOS. ${ }^{34}$ In patients without reflux oesophagitis, density of $H$ pylori and severity of gastritis in the cardia and antrum are similar, ${ }^{34}$ probably because the type of gastric epithelium and the}


local $\mathrm{pH}$ that determines the growth behaviour of $H$ pylori are quite similar in these regions of the stomach. ${ }^{35}$ In patients with reflux oesophagitis, however, we observed lower cardial gastritis activity and lower bacterial density. ${ }^{36}$ We assume that this phenomenon is secondary to increased exposure of the cardia to acid in reflux disease.

$H$ pylori gastritis is accompanied by the release of numerous mediators, cytokines and nitric oxide ${ }^{37} 38$ which may adversely affect the $\operatorname{LOS}^{39} 40$ and possibly promote an inflammatory response in, and mucosal damage to, the adjacent oesophageal mucosa. Also, $H$ pylori infection leads to increased production of prostaglandins ${ }^{41}$ which, in addition to inflammatory mediators, can sensitise afferent nerves and reduce LOS pressure. ${ }^{42}$ There is good evidence to indicate that the excessive production of prostaglandins in reflux oesophagitis drives a vicious cycle of LOS dysfunction, reflux, mucosal inflammation, aggravated LOS dysfunction, and further reflux. ${ }^{43}$ Hypothetically, inflammation in the upper part of the stomach may lower the threshold for triggering transient relaxation of the LOS - for example, by altering the sensitivity of vagal sensory receptors. ${ }^{44}$

It has been shown convincingly that $H$ pylori infection with antrum predominant gastritis is associated with an augmented gastrin release, both in the fasting state and after infusion of gastrin-releasing peptide. ${ }^{45}$ This also holds true for healthy subjects and patients with duodenal ulcer. It is conceivable that, at least in some patients with GORD, increased acidity along with a higher volume of gastric juice may aggravate reflux disease.

About half of the patients with GORD show some degree of delayed gastric emptying. Antral gastritis may interfere with gastric emptying, and some studies suggest abnormalities of gastric motor function in $H$ pylori infected dyspeptic subjects, ${ }^{46}$ but data on this are controversial. ${ }^{47-51}$

$H$ pylori may theoretically affect the compliance of the gastric wall, and in this way favour gastro-oesophageal reflux by increasing the gastro-oesophageal pressure gradient after a meal. However, a recent study investigating the mechanical properties of the gastric wall failed to find any differences between healthy subjects and patients with functional dyspepsia either with or without $H$ pylori infection..$^{52}$ Studies in patients with reflux are still lacking.

Direct injurious effects on the oesophageal mucosa could also be caused by bacterial factors such as cytotoxin, phospholipase and ammonia derivates, which might well be strain dependent.

\section{Mechanisms by which $H$ pylori might protect against GORD}

$H$ pylori infection may lower intragastric acidity. In vitro, $H$ pylori has been shown to release substances that inhibit gastric acid secretion..$^{53}$ Moreover, $H$ pylori generates large amounts of ammonia. ${ }^{55}$ Ammonia has a high $\mathrm{pKa}$ of 9.1 and acts as a powerful neutralising substance at elevated gastric $\mathrm{pH}$ while having no effect on the physiological $\mathrm{pH}$ in the spontaneously secreting stomach. Ammonia could, therefore, decrease the corrosive potential of the gastric juice refluxing into the oesophagus where the $\mathrm{pH}$ is high.

The amount of acid secreted in the infected stomach largely depends on the severity of corpus gastritis. More severe corpus gastritis is associated with lower acid output that returns to normal when the infection has been cured. ${ }^{567}$ This effect is probably mediated by cytokines such as interleukin-1 $\beta$, nitric oxide and a loss of M3 receptors in moderate, but not in mild, corpus gastritis. ${ }^{58-61}$ Bicarbonate leakage from the inflamed mucosa and intramural back-diffusion of acid may also lower the acidity in the infected stomach. ${ }^{62}$ Finally, $H$ pylori gastritis may progress to multifocal atrophic gastritis with destruction of gastric glands and, in turn, hypochlorhydria. ${ }^{63}$ That corpus gastritis plays a critical role is supported by a study showing that patients with reflux symptoms without oesophagitis more often had active corpus gastritis than did patients with GORD with erosive oesophagitis. ${ }^{64}$ Also, the severity of corpus gastritis before cure of $H$ pylori infection in patients with duodenal ulcer was a risk factor for the development of reflux oesophagitis after the cure. ${ }^{65}$

It has been shown repeatedly that $H$ pylori infection is associated with raised serum gastrin concentrations that decrease after cure of the infection. ${ }^{45}{ }^{66}$ Although controversial, gastrin, even at physiological concentrations, may increase the LOS pressure. ${ }^{67} 68$ This effect might even be more pronounced in patients with reduced acid output as a consequence of moderate to severe corpus gastritis.

Ammonia leads to protective mucosal adaptation in the rat stomach. ${ }^{69}$ As ammonia appears in the gastric juice refluxing into the oesophagus, it is conceivable that ammonia, like other mucosal irritants, ${ }^{20}$ may also lead to protective adaptation of the oesophageal mucosa.

\section{Clinical observations and $H$ pylori treatment trials}

Anecdotal reports indicate that some patients with GORD experience relief from reflux symptoms following the cure of $H$ pylori infection. Controlled studies on this issue are, however, still lacking. In a prospective clinical study in patients with functional dyspepsia, we found $H$ pylori infection to be more frequently associated with reflux symptoms. ${ }^{70}$ It has also been reported that patients with reflux-like functional dyspepsia may benefit from cure of the infection, ${ }^{71}$ and this holds true for some patients with peptic ulcer disease and reflux symptoms. ${ }^{72-74}$ However, these studies were uncontrolled, and reflux symptoms such as heartburn or regurgitation, which were considered in all these studies, are not specific. ${ }^{75}$

Conversely, it has been reported that reflux oesophagitis may develop in healthy subjects and in patients with duodenal ulcer after successful treatment of $H$ pylori infection. ${ }^{76}{ }^{77}$ As GORD is a common disorder, this finding in small scale studies may be coincidental. However, in a large, controlled study we found that about one quarter of patients with duodenal ulcer cured of their $H$ pylori infection developed endoscopically diagnosed reflux oesophagitis within three years of cure. This was double the rate we observed in patients with duodenal ulcer with ongoing infection. ${ }^{65}$

\section{Impact of $H$ pylori on the efficacy of antisecretory drugs}

Proton pump inhibitors (PPIs) are without doubt the most effective drugs in the control of GORD. ${ }^{78}$ Pharmacological studies showed that omeprazole is less effective, with respect to acid control, in healthy subjects than in patients with duodenal ulcer ${ }^{79} 80$ despite the known acid hypersecretion in the majority of the latter. In healthy subjects, omeprazole was less effective in the absence of $H$ pylori infection, ${ }^{81}$ and curing the infection noticeably decreased the $\mathrm{pH}$ increasing effect of omeprazole over the short and long term, ${ }^{82}$ with neutralising ammonia generated by $H$ pylori being the most likely explanation. ${ }^{83}$ Similar experiments in patients with duodenal ulcer confirmed these observations. ${ }^{84}$ The loss of efficacy of ranitidine on nocturnal intragastric acidity after cure of the infection was less pronounced. ${ }^{85}$ As intragastric $\mathrm{pH}$ is linearly related to the healing rate of reflux oesophagitis ${ }^{78}$ and as, within a 24 hour period in patients with duodenal ulcer, the total time during which the $\mathrm{pH}$ was $\geqslant 4$ was twice as long before the cure of $H$ pylori infection as after, ${ }^{86}$ studies in reflux patients with 
A

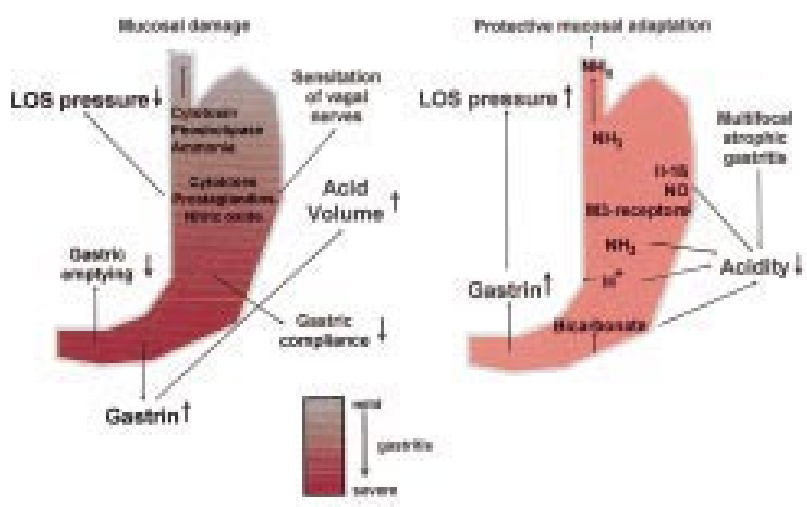

Figure 1: Proposed mechanisms by which $H$ pylori infection could aggravate $(A)$, or protect against $(B), G O R D$. In condition $A$ the gastritis is antrum predominant (antrum $>$ corpus). In condition $B$ the gastritis involves all regions of the stomach to the same degree (corpus $\geqslant$ antrum). It is of note that the cardia is always inflamed.

special emphasis on the dosage of a PPI needed after the cure are urgently required to determine the clinical relevance of this observation.

\section{Does $H$ pylori increase the risk of maintenance treatment with antisecretory drugs?}

Several studies have shown that treatment with PPIs is associated with worsening of corpus gastritis in $H$ pylori infected patients. ${ }^{87} 88$ There is also circumstantial evidence that lower gastric acidity is associated with a higher than usual incidence of atrophic gastritis. ${ }^{89}$ The first (and only) controlled study suggested that PPI maintenance treatment in $H$ pylori positive patients with GORD may accelerate the development of atrophic corpus gastritis. ${ }^{90}$ However, this study is scientifically flawed by incorporation of an inappropriate control group. An FDA Advisory Committee, therefore, concluded that there is no evidence whatsoever that long term treatment with antisecretory drugs increases the risk of gastric atrophy, intestinal metaplasia, or gastric cancer. Although we agree with the experts final conclusion, we are not convinced that increased severity of corpus gastritis is completely without relevance, as a recent case control study has suggested that corpus predominant gastritis in terms of mono- and polymorphonuclear cell infiltration increases the risk of gastric cancer. ${ }^{91}$

\section{Conclusions}

The inter-relation between $H$ pylori infection and GORD is complex and not fully understood. Epidemiological data have not shown that patients with GORD are more likely to be infected with $H$ pylori, but there are plenty of possible mechanisms by which the infection could theoretically contribute to this multifactorial disease (fig 1). Clinical observations and the results of $H$ pylori treatment trials are not conclusive, and appropriately controlled eradication studies in patients with reflux disease are urgently needed. Epidemiological data, pathogenic considerations and the observation that curing the infection increases the risk of reflux oesophagitis in patients with duodenal ulcer are consistent with the hypothesis that $H$ pylori infection may, at least in some patients, protect against reflux disease (fig 1). The topography of $H$ pylori gastritis could be the crucial point, with an antrum predominant gastritis aggravating reflux disease and pangastritis or corpus predominant gastritis protecting the oesophagus against damage by gastric juice. Curing the infection in GORD may have the disadvantage of reducing the efficacy of antisecretory treatment; conversely, it may prevent worsening of corpus gastritis. Further studies are urgently needed to identify those patients in whom $H$ pylori is a friend/foe of the oesophagus, and to permit the development of clinical guidelines on a sound scientific basis.

\section{JOACHIM LABENZ PETER MALFERTHEINER}

Department of Gastroenterology, Hepatology

and Infectious Diseases,

Otto-von-Guericke University

Magdeburg, GermanyCorrespondence to: Professor P Malfertheiner, Department of Gastroenterology, Hepatology and Infectious Diseases, Otto-vonGuericke University, Leipziger Strasse 44, 39120 Magdeburg, Germany.

1 Hopkins RJ, Girardi LS, Turney EA. Relationship between Helicobacter pylori eradication and reduced duodenal and gastric ulcer recurrence: a pylori eradication and reduced duodenal and
review. Gastroenterology 1996; 110: 1244-52.

2 Kreiss C, Blum AL, Malfertheiner P. Peptic ulcer pathogenesis. Curr Opin Gastroenterol 1995; 11 (suppl 1): 25-31.

3 Forman D. Helicobacter pylori and gastric cancer. Scand $\mathcal{f}$ Gastroenterol 1996; 31 (suppl 215): 48-51.

4 Bayerdörffer E, Neubauer A, Rudolph B, Thiede C, Lehn N, Eidt S, et al. Regression of primary gastric lymphoma of mucosa-associated lymphoid tissue type after cure of Helicobacter pylori infection. Lancet 1995; 345: 1591-4.

5 Boyd EJS. The prevalence of esophagitis in patients with duodenal ulcer or ulcer-like dyspepsia. Am f Gastroenterol 1996; 91: 1539-43.

6 Fink SM, Barwick KW, DeLuca V, Sanders FJ, Kandathil M, McCallum Fink SM, Barwick KW, DeLuca V, Sanders FJ, Kandathil M, McCallum
RW. The association of histological gastritis with gastroesophageal reflux RW. The association of histological gastritis with gastroesophageal
and delayed gastric emptying. F Clin Gastroenterol 1984; 6: 301-9.

7 Tytgat GNJ. Role of Helicobacter pylori infection in gastro-oesophageal reflux disease. In: Hunt RH, Tytgat GNJ, eds. Helicobacter pylori. Basic mechanisms to clinical cure 1996. Dordrecht: Kluwer Academic Publishers, 1996: 304-11.

8 Mihara M, Haruma K, Kamada T, Kiohyra K, Goto T, Sumii M, et al. Low prevalence of Helicobacter pylori infection in patients with reflux esophagitis [abstract]. Gut 1996; 39 (suppl 2): A94.

9 Hackelsberger A, Schultze V, Günther T, Labenz J, Kahl S, DominguezMunoz JE, et al. $\mathrm{H}$. pylori prevalence in reflux esophagitis- a case-control study [abstract]. Gastroenterology 1997; 112: A137.

10 Spechler SJ. Epidemiology and natural history of gastro-oesophageal reflux disease. Digestion 1992; 51 (suppl 1): 24-9.

11 The Eurogast Study Group. An international association between Helicobacter pylori infection and gastric cancer. Lancet 1993; 311: 1359-62.

12 Lööf L, Götell P, Elfberg B. The incidence of reflux oesophagitis. A study of endoscopy reports from a defined catchment area in Sweden. Scand $\mathcal{F}$ Gastroenterol 1993; 28: 113-8.

13 Loffeld RJLF, Ten Tige BJ, Arends JW. Prevalence and significance of Helicobacter pylori in patients with Barrett's esophagus. Am f Gastroenterol 1992; 87: 1598-600

14 Ectors N, Geboes K, Janssens J, Vantrappen G. Helicobacter pylori and the oesophagus. In: Pajares JM, Pena S, Malfertheiner P, eds. $H$ pylori and gastroduodenal pathology. Berlin: Springer Verlag, 1993: 142-50.

15 Marshall BJ. Epidemiology of H. pylori in Western countries. In: Hunt RH, Tytgat GNJ, eds. Helicobacter pylori. Basic mechanisms to clinical cure. Dordrecht: Kluwer Academic Publishers, 1994: 75-84.

16 Hesketh PJ, Clapp RW, Doos WG, Spechler SJ. The increasing frequency of adenocarcinoma of the esophagus. Cancer 1989; 64: 526-30

17 Graham DY, Malaty HM, Evans DG, Evans DJ, Klein PD, Adam E. Epidemiology of Helicobacter pylori in an asymptomatic population in the United States. Effect of age, race and socioeconomic status. Gastroenterology 1991; 100: 1495-501.

18 Molloy RM, Sonnenberg A. History of peptic ulcer in cardiac and non-cardiac cancer of the stomach [abstract]. Gastroenterology 1996; 110: A200.

19 Dent J, Halloway RH, Tooulis J, Dodds WJ. Mechanism of lower esophageal sphincter incompetence in patients with asymptomatic gastro-oesophageal reflux. Gut 1988; 29: 1020-9.

20 Galmiche JP, Janssens J. The pathophysiology of gastro-oesophageal reflux disease: an overview. Scand f Gastroenterol 1995; 30 (suppl 211): 7-18.

21 Hirshowitz BI. A critical analysis, with appropriate controls, of gastric acid and pepsin secretion in clinical esophagitis. Gastroenterology 1991; 101: and pepsin.

22 Miller LS, Vinayek R, Frucht H, Gardner JD, Jensen RT, Maton PN. Reflux esophagitis in patients with Zollinger-Ellison syndrome. Gastroenterology 1990; 98: 341-6.

23 Collen MJ, Lewis JH, Benjamin SB. Gastric acid hypersecretion in refractory gastroesophageal reflux disease. Gastroenterology 1990; 98: 654-61.

24 McCallum RW, Berkowitz DM, Lerner E. Gastric emptying in patients with gastroesophageal reflux. Gastroenterology 1981; 80: 285-91.

25 Scarpignato C, Franzé A. Esophageal exposure to acid in GERD patients with and without delayed gastric emptying. Effect of cisapride. Hepatogastroenterology 1992; 39: 91-92.

26 Hartley MN, Walker SJ, Mackie CR. Abnormal gastric adaptive relaxation in patients with gastroesophageal reflux. Gut 1990; 31: 500-3.

27 Kahrilas PJ, Dodds WJ, Hogan WJ, Kern M, Arndorffer RC, Reece A. Esophageal peristaltic dysfunction in peptic esophagitis. Gastroenterology 1986; 91: 897-904.

28 Meyers RL, Orlando R. In vivo bicarbonate secretion by human esophagus. Gastroenterology 1992; 103: 1174-8.

29 Orlando RC, Powell DW, Carney CN. Pathophysiology of acute acid injury in rabbit esophageal epithelium. F Clin Invest 1981; 68: 286-93. 
30 Shaker R, Kahrilas PJ, Dodds WJ, Hogan WJ. Oesophageal clearance of small amounts of equal or less than one mililitre of acid. Gut 1992; 33: small

31 Castell DO. Obesity and gastro-oesophageal reflux: is there a relationship? Eur f Gastroenterol Hepatol 1996; 8: 625-6.

32 Kahrilas PJ. Cigarette smoking and gastroesophageal reflux disease. Dig Dis 1992; 10: 61-71.

33 Kaufman SE, Kaye MD. Induction of gastro-oesophageal reflux by alcohol. Gut 1978; 19: 336-8.

34 Genta RM, Huberman RM, Graham DY. The gastric cardia in Helicobacter pylori infection. Hum Pathol 1994; 25: 915-9.

35 Meyer-Rosberg K, Scott DR, Rex D, Melchers K, Sachs G. The effect of environmental $\mathrm{pH}$ on the proton motive force of Helicobacter pylori. Gastroenterology 1996; 111: 886-900.

36 Hackelsberger A, Schultze V, Günther T, Malfertheiner P. The relationship between H. pylori gastritis and GERD [abstract]. Gut 1996; 39 (suppl 2): A25.

37 Noach LA, Bosma NB, Jansen J, Hoek FJ, van Deventer SJ, Tytgat GN. Mucosal tumor necrosis factor-alpha, interleukin-1 beta, and interleukin-8 production in patients with Helicobacter pylori infection. Scand $\mathcal{f}$ Gastroenterol 1994; 29: 425-9.

38 Wilson KT, Ramanujam KS, Mobley HLT, Musselman RF, James SP, Meltzer SJ. Helicobacter pylori stimulates inducible nitric oxide synthase expression and activity in a murine macrophage cell line. Gastroenterology 1996; 111: 1524-33.

39 Boulant J, Fioramonti J, Dapoigny M, Bommelaer G, Buleno L. Cholecystokinin and nitric oxide in transient lower esophageal sphincter relaxation to gastric distension in dogs. Gastroenterology 1994; 107: 1059-66.

40 Preikseitis HG, Tremblay L, Diamant NE. Nitric oxide mediates inhibitory nerve effects in human esophagus and lower esophageal sphincter. Dig Dis Sci 1994; 39: 770-5.

41 Laine L, Cominelli F, Sloane R, Casini-Raggi V, Marin-Sorensen M. Interaction of NSAIDs and Helicobacter pylori on gastrointestinal injury and prostaglandin production: a controlled double-blind trial. Aliment Pharmacol Ther 1995; 9: 127-35.

42 Mukhopadhyyay A, Rattan S, Goyal RK. Effect of prostaglandin E2 on esophageal motility in man. $\mathcal{f}$ Appl Physiol 1975; 39: 479-81.

43 Morgan GP. Deleterious effects of prostaglandin E2 in reflux oesophagitis. Med Hypotheses 1996; 46: 42-4

44 Mittal RK, Holloway RH, Penagini R, Blackshaw LA, Dent J. Transient lower esophageal sphincter relaxation. Gastroenterology 1995; 109: 601-10.

45 El-Omar EM, Penman ID, Ardill JES, Chittajallu RS, Howie C, McColl $\mathrm{KE}$. Helicobacter pylori infection and abnormalities of acid secretion in patients with duodenal ulcer disease. Gastroenterology 1995; 109: 681-91.

46 Qvist N, Rasmussen L, Axelsson CK. Helicobacter pylori-associated gastritis and dyspepsia. The influence on migrating motor complexes. Scand $\mathcal{F}$ Gastroenterol 1994; 29: 133-7.

$47 \mathrm{Kao} \mathrm{CH}$, Wang SJ, Chen $\mathrm{GH}$, Yeh $\mathrm{SH}$. The relationship between Helicobacter pylori-associated gastritis or ulcer disease and gastric emptying. Eur F Nucl Med 1994; 21: 209-11.

48 Pieramico O, Ditschuneit H, Malfertheiner P. Gastrointestinal motility in patients with non-ulcer dyspepsia: a role for Helicobacter pylori infection? Am $\mathcal{F}$ Gastroenterol 1993; 88: 364-8.

49 Scott AM, Kellow JE, Shuter B, Cowan H, Corbett AM, Riley JW, et al. Intragastric distribution of solids and liquids in functional dyspepsia. Lack of influence of symptom subgroups and Helicobacter pylori-associated of influence of symptom subgroups and
gastritis. Dig Dis Sci 1993; 38: 2247-54.

50 Tucci A, Corinaldesi R, Stanghellini V, Tosetti C, Di Febo G, Paparo GF, et al. Helicobacter pylori infection and gastric function in patients with
chronic idiopathic dyspepsia. Gastroenterology 1992; 103: 768-74.

51 Wegener M, Börsch G, Schaffstein J, Schulz-Flake C, Mai U, Leverkus F Are dyspeptic symptoms in patients with Campylobacter pylori-associated type $\mathrm{B}$ gastritis linked to delayed gastric emptying? Am $\mathcal{F}$ Gastroenterol 1988; 83: $737-40$

52 Mearin F, de Ribot X, Balboa A, Salas A, Varas MJ, Cucala M, et al. Does Helicobacter pylori infection increase gastric sensitivity in functional dyspepsia? Gut 1995; 37: 47-51.

53 Beil W, Birkholz C, Wagner S, Sewing K-F. Interaction of Helicobacter pylori and its fatty acids with parietal cells and gastric $\mathrm{H}^{+} / \mathrm{K}^{+}$-ATPase. Gut 1994; 25: 1176-80.

54 Cave DR, Vargas M. Effect of a Campylobacter pylori protein on acid secretion by parietal cells. Lancet 1989; ii: 187-9.

55 Goggin PM, Marrero JM, Ahmed H, Jackson PA, Corbishley CM, Northfield TC. Urea hydrolysis in Helicobacter pylori infection. Eur 7 Gastroenterol Hepatol 1991; 3: 927-33.

56 Feldman M, Cryer B, McArthur KE, Lee E. Relationship between severity of $\mathrm{H}$. pylori (HP) gastritis and gastric acid-pepsin secretion in man of $\mathrm{H}$. pylori (HP) gastritis and gastric acid
[abstract]. Gastroenterology 1996; 110: A106

57 Yasunaga Y, Shinimura Y, Kanayama S, Yabu M, Nakanishi T, Miyazaki Y, et al. Improved fold width and increased acid secretion after eradication of the organism in Helicobacter pylori associated enlarged fold gastritis. Gut 1994; 35: 1571-4.

58 Esplugues JV, Barrachina MD, Calatayud S, Pique JM, Whittle BJ. Nitric oxide mediates the inhibition by interleukin-1 beta of pentagastrinstimulated rat gastric acid secretion. Br f Pharmacol 1993; 108: 9-10. 59 McGowan CC, Cover TL, Blaser MJ. Helicobacter pylori and gastric acid: 926-38.

60 Pfeiffer A, Krömer W, Friemann J, Ruge M, Herawi M, Schätzl M, et al. Muscarinic receptors in gastric mucosa are increased in peptic ulcer disease. Gut 1995; 36: 813-8.

61 Robert A, Olafsson AS, Lancaster C, Zhang WR. Interleukin-1 is cytoprotective, antisecretory, stimulates PGE2 synthesis by the stomach, and retards gastric emptying. Life Sci 1991; 48: 123-34.

62 Takeuchi K, Ohuchi T, Okabe S. Effects of nitric oxide synthase inhibitor $\mathrm{N}^{\mathrm{g}}$-nitro-L-arginine methyl ester on duodenal alkaline secretory and
ulcerogenic responses induced by mepirizole in rats. Dig Dis Sci 1995; 40: 670-7.
63 Kuipers EJ, Uyterlinde AM, Pena AS, Roosendaal R, Pals G, Nelis GF, et al. Long-term sequelae of Helicobacter pylori gastritis. Lancet 1995; 345:

64 De Koster E, Ferhat M, Deprez C, Deltenre M. Helicobacter pylori, gastric histology and gastro-oesophageal reflux disease [abstract]. Gut 1995; 37 (suppl 1): A36.

65 Labenz J, Blum AL, Bayerdörffer E, Meining A, Stolte M, Börsch G. Curing Helicobacter pylori infection in patients with duodenal ulcer may provoke reflux esophagitis. Gastroenterology 1997; 112: 1442-7.

66 Konturek JW, Gillessen A, Konturek SJ, Domschke W. Eradication of Helicobacter pylori restores the inhibitory effect of cholecystokinin on postprandial gastrin release in duodenal ulcer patients. Gut 1995; 37: 482-7.

67 Allescher HD, Stoschus B, Wünsch E, Schusdziarra V, Classen M. Effect of human gastrin-17 with and without acid suppression on human esophageal motility. Z Gastroenterol 1995; 33: 385-91.

68 McCallum R, Walsh JH. Relationship between lower esophageal sphincter pressure and serum gastrin concentration in Zollinger-Ellison syndrome and other clinical settings. Gastroenterology 1979; 76: 76-81.

69 Konturek SJ, Konturek PJ, Brzozowski T, Stachnura J, Zombala M. Gastric mucosal damage and adaptive protection by ammonia and ammonium ions in rats. Dig Dis Sci 1996; 57: 433-45.

70 Pieramico O, Malfertheiner P. Helicobacter pylori infection in gastroesophageal reflux disease. In: Pajares JM, Pena S, Malfertheiner P, eds. Helicobacter pylori and gastroduodenal pathology. Berlin: Springer Verlag, 1993: 207-10.

71 Trespi E, Broglia F, Villani I, Luinetti O, Fiocca R, Solcia E. Distinct profiles of gastritis in dyspepsia subgroups. Their different clinical responses to gastritis healing after Helicobacter pylori eradication. Scand $\mathcal{f}$ Gastroenterol 1994; 29: 884-8.

72 Phull PS, Ryder SD, Halliday D, Price AB, Levi AJ, Jacyna MR. The economic and quality-of-life benefits of Helicobacter pylori eradication in chronic duodenal ulcer disease - a community-based study. Postgrad Med $\mathcal{F}$ 1995; 71: 413-8.

73 Powell KU, Bell GD, Bolton GH, Burridge SM, Bowden AF, Rameh B, et al. Helicobacter pylori eradication in patients with peptic ulcer disease: clinical consequences and financial implications. Qf Med 1994; 87: 283-90.

74 Reilly TG, Ayres RCS, Poxon V, Walt RP. Helicobacter pylori eradication in a clinical setting: success rates and the effect on the quality of life in peptic ulcer. Aliment Pharmacol Ther 1995; 9: 483-90.

75 Johnsson F, Joelsson B, Gudmundsson K, Greiff L. Symptoms and endoscopic findings in gastroesophageal reflux disease. Scand $\mathcal{F}$ Gastroenterol 1987; 22: 714-8.

76 Schütze K, Hentschel E, Dragosics B, Hirschl AM. Helicobacter pylori reinfection with identical organisms: transmission by the patients' spouses. Gut 1995; 36: 831-3.

77 Verdú E, Armstrong D, Idström J-P, Labenz J, Stolte M, Börsch G, et al. Intragastric $\mathrm{pH}$ during treatment with omeprazole: role of Helicobacter pylori and H. pylori-associated gastritis. Scand f Gastroenterol 1996; 31: $1151-6$

78 Bell NJV, Burget D, Howden CW, Wilkinson J, Hunt RH. Appropriate acid suppression for the management of gastro-esophageal reflux disease. Digestion 1992; 51 (suppl 1): 59-67.

79 Cederberg C, Röhss K, Lundborg P, Olbe L. Effect of once daily intravenous and oral omeprazole on 24-hour intragastric acidity in healthy subjects. Scand $\mathcal{F}$ Gastroenterol 1993; 28: 179-84.

80 Cederberg C, Thomas ABR, Mahachal V, Westin JA, Kirdeikis P, Fisher D, et al. Effect of intravenous and oral omeprazole on 24-hour intragastric acidity in duodenal ulcer patients. Gastroenterology 1992; 103: 913-8.

81 Verdú E, Armstron D, Fraser R, Viani F, Idström J-P, Cederberg C, et al. Effect of Helicobacter pylori status on intragastric $\mathrm{pH}$ during treatment with omeprazole. Gut 1995; 36: 539-43.

82 Verdú EF, Armstrong D, Idström J-P, Labenz J, Stolte M, Dorta G, et al. Effect of curing Helicobacter pylori infection on intragastric $\mathrm{pH}$ during treatment with omeprazole. Gut 1995; 37: 743-8.

83 Bercik P, Verdú EF, Armstrong D, Cederberg C, Idström J-P, Stolte M, et al. $\mathrm{H}$. pylori related increase in omeprazole (OME) effect is associated with ammonia production [abstract]. Gastroenterology 1996; 110: A64

84 Labenz J, Tillenburg B, Peitz U, Idström J-P, Verdú EF, Stolte M, et al. Helicobacter pylori augments the $\mathrm{pH}$-increasing effect of omeprazole in patients with duodenal ulcer. Gastroenterology 1996; 110: 725-32.

85 Labenz J, Tillenburg B, Peitz U, Verdú EF, Stolte M, Börsch G, et al. Effect of curing Helicobacter pylori infection on intragastric acidity during treatment with ranitidine in patients with duodenal ulcer. Gut 1997; 41: 33-6.

86 Labenz J, Tillenburg B, Peitz U, Idström J-P, Verdú E, Stolte M, et al. Efficacy of omeprazole one year after cure of Helicobacter pylori infection in duodenal ulcer patients. Am f Gastroenterol 1997; 92: 576-8.

87 Kuipers EJ, Uyterlinde AM, Pena AS, Hazenberg HJA, Bloemena E, Lindeman J, et al. Increase of Helicobacter pylori-associated corpus gastritis during acid suppressive therapy: Implications for long-term safety. Am f Gastroenterol 1995; 90: 1401-6.

88 Solcia E, Fiocca R, Villani L, Carlsson J, Rudbäck A, Zeijlon L. Effects of permanent eradication or transient clearance of Helicobacter pylori on histology of gastric mucosa using omeprazole with or without antibiotics. Scand f Gastroenterol 1996; 31 (suppl 215): 105-10.

89 Kuipers EJ, Lee A, Klinkenberg-Knol EC, Meuwissen SGM. Review article: the development of atrophic gastritis-Helicobacter pylori and the effects of acid suppressive therapy. Aliment Pharmacol Ther 1995; 9: 331-40.

90 Kuipers EJ, Lundell L, Klinkenberg-Knol EC, Havu N, Festen HPM, Liedman B, et al. Atrophic gastritis and Helicobacter pylori infection in patients with reflux esophagitis treated with omeprazole or fundoplication. $\mathrm{N} \mathrm{Engl} \mathcal{f}$ Med 1996; 334: 1018-22

91 Meining A, Stolte M, Müller P, Lehn N, Hölzel D, Bayerdörffer E. Gastric carcinoma risk index in patients infected with Helicobacter pylori [abstract]. Gastroenterology 1996; 110: A556. 